Ratifying the Republic 



\title{
Ratifying the Republic
}

Antifederalists and Federalists in Constitutional Time

\author{
David J. Siemers
}

STANFORD UNIVERSITY PRESS

Stanford, California 
Stanford University Press

Stanford, California

(C) 2002 by the Board of Trustees of the

Leland Stanford Junior University

All rights reserved.

Library of Congress Cataloging-in-Publication Data

Siemers, David J.

Ratifying the republic: Antifederalists and

Federalists in constitutional time / David J. Siemers.

p. $\mathrm{cm}$.

Includes bibliographical references and index.

ISBN 0-8047-4106-9 (cloth : alk paper)

I. United States-Politics and government-

1789-I809. 2. Politicial science-United States-

History. 3. Legitimacy of governments-United

States-History. 4. Constitutional history-United

States. I. Title.

JKII6.s54 2002

320.473'049'09033-dc2I 2002003102

Original Printing 2002

Last figure below indicates year of this printing:

$\begin{array}{llllllllll}\text { II } & 10 & 09 & 08 & 07 & 06 & 05 & 04 & 03 & 02\end{array}$

Designed by Eleanor Mennick

Typeset by BookMatters in $\mathrm{ro} / \mathrm{I} 2$ Sabon and Galliard 
For my family,

with respect and affection 
